\title{
INOVASI GURU DALAM PEMBELAJARAN SAINS UNTUK MENINGKATKAN KOMPETENSI DAN KREATIVITAS SISWA
}

\author{
Yuli Filindity ${ }^{1}$, Victor Kayadoe ${ }^{1}$ \\ ${ }^{1}$ Program Studi Pendidikan Kimia Jurusan Pendidikan MIPA FKIP Universitas Pattimura, \\ Ambon
}

\begin{abstract}
ABSTRAK. Pendidikan sains menitikberatkan pada pemberian pengalaman langsung untuk mengembangkan kompetensi sehingga siswa mampu menjelajahi dan memahami alam sekitar secara ilmiah. Hal ini hanya dapat dilakukan bila guru melakukan inovasi pembelajaran menggunakan prinsip pembelajaran bermakna dan menyenangkan selain lebih menyenangkan para siswa, juga dapat memberikan efek iringan, yaitu dapat meningkatkan kreativitas siswa.
\end{abstract}

Kata Kunci: Inovasi guru, pembelajaran sains, kompetensi, kreativitas siswa

\section{Pendahuluan}

Ilmu Pengetahuan Alam (IPA) atau sains merupakan salah satu pelajaran yang diajarkan mulai dari Sekolah Dasar sampai Perguruan Tinggi, namun sampai saat ini banyak siswa yang kurang menyukai sains, siswa menganggap sains sebagai materi yang sulit dan tidak menyenangkan, dengan demikian agar pembelajaran sains lebih menarik dan menyenangkan siswa, maka guru perlu melakuakan inovasi-inovasi dalam pembelajaran. Inovasi dalam pembelajaran sains selain lebih menyenangkan para siswa, juga dapat memberikan efek iringan, yaitu dapat meningkatkan kreativitas siswa.

Salah satu inovasi dalam pembelajaran sains adalah melakukan pembelajaran sains melalui dengan inovasiinovasi yang sederhana yang mampu membawa siswa untuk belajar mengenal lingkungan sekitar yang secara nyata siswa mengalami, disisi lain peran guru akan memungkinkan suasana belajar menjadi lebih menyenangkan salah satunya adalah peran guru sebagai pengelola lingkungan belajar, sehingga guru harus mampu menciptakan lingkungan belajar yang kondusif agar siswa dapat belajar secara optimal. Lingkungan belajar yang secara resmi menjadi tanggung jawab guru IPA tidak hanya meliputi kelas dengan batas-batas berupa dinding kelas atau laboratorium, tetapi juga lingkungan sekitar/alam, artinya guru tersebut harus dapat menjembatani interaksi belajar antar siswa. Di samping itu guru juga dapat memberikan berbagai fasilitas lainnya yang diperlukan bagi siswa, antara lain berupa alat bantu atau media pembelajaran yang menunjang, serta melengkapi fasilitas yang diperlukan untuk terjadinya pembelajaran yang optimal, misalnya pada pembelajaran MIPA, terdapat kegiatan eksperimen yang dilakukan di laboratorium, maka guru harus menyiapkan fasilitas-fasilitas untuk keberlangsungan kegiatan eksperimen, dengan demikian, maka sudah saatnya bagi guru untuk mencoba mengembangkan profesionalismenya melalui pengembanganl pembelajaran yang mampu mengaktifkan dan menciptakan kondisi pembelajaran yang aktif, inovatif, kreatif, efektif, dan sekaligus menyenangkan. Dengan demikian peserta didik akan merasakan kebermaknaan belajar bagi hidup dan kehidupannya dan akhirnya meaningful learning akan terwujud. Tujuan: mengetahui inovasi-inovasi guru dalam pembelajaran IPA/ sains.

\section{Kajian Teori}

\subsection{Pembelajaran IPA}

Pembelajaran IPA di sekolah diharapkan dapat menjadi wahana bagi siswa untuk mempelajari alam sekitar. Pendidikan sains menekankan pada pemberian pengalaman langsung untuk mengembangkan kompetensi agar siswa mampu menjelajahi dan memahami alam sekitar secara ilmiah. Pendidikan sains diarahkan untuk "mencari tahu" dan "berbuat" sehingga dapat membantu siswa untuk memperoleh pemahaman yang lebih mendalam tentang alam sekitar. Pendekatan yang diterapkan dalam menyajikan pembelajaran sains adalah memadukan antara pengalaman proses sains dan pemahaman produk serta teknologi sains dalam bentuk pengalaman langsung yang berdampak pada sikap siswa yang mempelajari sains.

Lebih dari itu pendekatan yang digunakan dalam pembelajaran sains berorientasi pada siswa. Peran guru beralih dari menentukan "apa yang akan dipelajari" ke "bagaimana menyediakan dan memperkaya pengalaman 
belajar siswa". Pengalaman belajar diperoleh melalui serangkaian kegiatan untuk mengeksplorasi lingkungan melalui interaksi aktif dengan teman, lingkungan, dan sumber belajar yang lain.

\subsection{Pendekatan Kontekstual Berbasis Lingkungan}

Ketiadaan alat dan bahan laboratorium sering menjadi kendala tidak dilakukannya praktikum, meskipun guru pengampu memiliki petunjuk praktikumnya. Oleh karena itu sangat diperlukan kreativitas guru sains dalam mencari alternatif bahan dan alat lain yang dapat digunakan agar praktkum tetap dapat dilaksanakan. Dengan demikian pelaksanaan praktikum tidak bergantung pada fasilitas laboratorium yang ada di sekolah, tetapi cukup menggunakan bahan dan alat yang dengan mudah dijumpai dalam kehidupan sehari-hari (Saliraswati, 2010).

Metode praktikum sangat dianjurkan dalam pembelajaran Sains, karena sesuai dengan tujuan pendidikan yang meliputi 3 aspek, yaitu mengembangkan pengetahuan, menanamkan sikap ilmiah, dan melatih keterampilan. Melalui praktikum peserta didik memperoleh pemahaman yang mendalam tentang suatu konsep, sebab mereka melaku-kan dan melihat sendiri. Bila dilihat dari buku petunjuk praktikum yang sudah ada di lapangan, nampaknya tidak semua materi pokok yang ada dalam kurikulum mata pelajaran IPA terwakili oleh suatu topik percobaan. Ironisnya, sebagian besar buku petunjuk praktikum yang beredar di pasaran isinya sama, tidak ada yang memiliki kelebihan, misalnya menyajikan topik percobaan yang berbeda dan baru/aktual. Meskipun semua percobaan bertujuan mengaktifkan peserta didik, namun akan lebih menarik minat belajar peserta didik bila buku petunjuk praktikum berisikan aktivitas percobaan sederhana yang menarik dengan bahan dan alat yang digunakan dapat diperoleh di lingkungan sekitar, sehingga peserta didik dapat mencobanya di rumah (Saliraswati, 2010)

Bagaimanakah cara guru menciptakan suatu percobaan baru sehingga siswa tertantang dan tertarik untuk melakukannya? Suatu materi ajar dapat dikonstruksi menjadi percobaan dengan mengikuti langkah-langkah berikut ini yang di kemukakan oleh (Saliraswati, 2010) adalah sebagai berikut:

1. Pelajari secara mendalam materi ajar tersebut, lalu coba cari hubungan setiap konsep yang ada dengan fenomena yang ada dalam kehidupan sehari-hari.

2. Setelah kita menemukan suatu fenomena, cobalah berpikir bagaimana mengangkat fenomena tersebut menjadi suatu rancangan percobaan sederhana dengan mencari hubungannya dengan konsep kimia tertentu.

3. Buatlah langkah-langkah pengujian / pembuktiannya.

4. Ujicobalah sesuai dengan rancangan yang dibuat.

5. Tulis rancangan dengan format prosedur sederhana yang mudah dipahami

Untuk dapat menemukan fenomena yang berkaitan dengan materi ajar mungkin dirasa sulit, namun sebenarnya semakin banyak membaca buku dan membuka internet, semakin besar kepekaan siswa terhadap fenomena sains di sekitarnya.

\section{Hasil Penelitian}

\section{Inovasi-Inovasi Guru Sains}

Dalam Kamus Lengkap Bahasa Indonesia (1997), inovasi berarti penemuan sesuatu yang baru atau berbeda dengan sesuatu yang sudah ada sebelumnya. Sedangkan inovatif adalah bersifat memperkenalkan sesuatu yang baru.

Pembelajaran adalah suatu proses kegiatan yang berupaya membelajarkan anak didik. Jadi, inovasi pembelajaran adalah suatu aktivitas memperkenalkan sesuatu yang baru dalam upaya membelajarkan anak didik, atau memperkenalkan sesuatu yang baru ketika melakukan transfer pengetahuan, keterampilan, dan nilai-nilai pada anak didik. Pembelajaran inovatif adalah pembelajaran dengan memperkenalkan sesuatu yang berbeda yang belum dialami dari sebelumnya. Sesuatu yang baru tidak identik dengan sesuatu yang mahal. Apa yang nampaknya tidak penting bisa saja mampu membuat pembelajaran lebih hidup hanya karena guru mampu melakukan inovasi. Dalam penciptaan pembelajaran inovatif yang terpenting adalah kemauan dan keinginan guru untuk membuat belajar menjadi menarik untuk diikuti dan menghilangkan kebosanan peserta didik dalam belajar.

Melepaskan diri dari sesuatu yang sudah terpola bukanlah pekerjaan yang mudah. Beberapa hal yang mampu membangkitkan pikiran untuk menjadi kreatif antara lain : berfantasi atau mengemukakan gagasan / ide yang tidak umum, berada pada satu gagasan untuk beberapa saat, berani mengambil resiko, peka terhadap segala keajaiban, penasaran terhadap suatu kebenar-an, banyak membaca artikel penemuan yang membuatnya kagum.

Untuk dapat menciptakan pembelajaran inovatif maupun kreatif diperlukan tiga sifat dasar yang harus dimiliki siswa maupun guru, yaitu peka, kritis, dan kreatif terhadap fenomena yang ada di sekitarnya. Peka artinya orang lain tidak dapat melihat keterkaitannya dengan konsep yang ada dalam otak, mampu menangkapnya sebagai fenomena yang dapat dijelaskan dengan konsep yang dimiliki. Kritis artinya fenomena yang tertangkap oleh mata dan mampu diolah dalam pikiran hingga memunculkan berbagai pertanyaan untuk mencari jawabannya. Kreatif 
artinya dengan kepiawaian pola pikir yang didasari pemahaman yang mendalam tentang konsep-konsep tertentu lalu kita berusaha menjelaskan atau bahkan menciptakan suatu aktivitas yang mampu menjelaskan fenomena tersebut kepada diri sendiri atau orang lain.

Sebagai contoh seorang guru IPA dapat menciptakan kegiatan yang baru dalam menjawab mengapa telur itik yang lebih banyak dibuat telur asin dengan prinsip IPA yang telah dipelajari. Guru yang kreatif dan inovatif adalah guru yang mampu mengembangkan kegiatan yang beragam di dalam dan di luar kelas, membuat alat bantu/media sederhana yang dapat dibuat sendiri oleh anak didiknya. Demikian pula anak didik yang kreatif dan inovatif mampu merancang sesuatu, menulis dan mengarang, dan membuat refleksi terhadap semua kegiatan yang dilakukannya. Sesuai dengan pendapat Ausubel (1991) bahwa belajar akan bermakna jika anak didik dapat mengaitkan konsep yang dipelajari dengan konsep yang sudah ada dalam struktur kognitifnya, dan pendapat Bruner (1991) yang menyatakan belajar akan berhasil lebih baik jika selalu dihubungkan dengan kehidupan orang yang sedang belajar (anak didik). Melalui inovasi pembelajaran inilah, diharapkan ada perbaikan praktik pembelajaran ke arah yang lebih baik (Munro, 2005).

Adapun beberapa inovasi yang dapat dilakukan oleh guru Sains sebagai berikut :

a. Judul Percobaan : Air dan Minyak Bersatu

Tujuan : mengetahui sifat emulsifire (pencampur) pada detergen

Alat dan Bahan :

1 buah gelas transparan

$1 / 2$ gelas minyak goreng

$1 / 2$ gelas air

1 sendok makan detergen

Cara Kerja :

- isi gelas dengan air

- tuangkan minyak goreng kedalamnya

- minyak goreng dan air akan memisah

- tambahkan detergen ke dalam gelas, amati apa yang terjadi

- setelah di tabah detergen, minyak dan air akan bercampur.

Penjelasan :

Detergen memiiki sifat dwipolar artinya molekul detergen memiliki sifat hidrofil (suka air) dan lipofil (suka lemak). Setellah ditambah detergen, air dan minyak akan bersatu akrena molekul detergen dapat mengikat air dan minyak sekaligus.

b. Judul Percobaan : Pembiasan Cahaya

Tujuan : Membuktikan bahwa terjadi fenomena pembiasan cahaya merambat melalui dua media yang memiliki perbedaan kerapatan

Alat dan Bahan

1 buah gelas

1 batang pensil

Air dingin

Cara Kerja

- Isi gelas dengan air hingga penuh

- Masukan 1 batang pensil kedalam gelas tadi

- Amati pensil dari bagian luar gelas

- Pensil akan terlihat bengkok pada batas antara air dan udara

Penjelasan :

Pensil terlihat bengkok dikarenakan adanya proses pembiasan cahaya ketika cahaya merambat melalui dua medium yang berbeda.

c. Judul Percobaan : Kromatografi

Tujuan : Membuktikan adanya perbedaan laju kapilaritas zat cair secara kromatografi

Alat dan Bahan

Beberapa lembar daum bayam

Kertas putih dengan ukuran $3 \times 7 \mathrm{~cm}$

1 buah piring kecil 
Air

Saringan

Cara Kerja

- Haluskan daun bayam, baung ampas dan ambil airnya

- Larutkan sari daun bayam dengan sedikit air di dalam piring kecil

- Celupkan kertas putih, hingga kertas terelup 1-2 mm (posisi kertas tegak)

- Biarkan beberapa saat hingga air bayam merambat naik

Penjelasan :

Air sari daun bayam terdiri dari beberapa senyawa yang memiliki perbedaan laju rambat pada kertas. Senyawa-senyawa ini merambat pada kertas dengan laju berbeda sesuai dengan jenis kertas dan lama waktu rambatan. Oleh karena itu, akan berbentuk noda-noda pada kertas dengan ketinggian yang berbeda-beda.

d. Judul Percobaan : Efek Tyndall

Tujuan : Mengetahui adanya sifat Tyndall pada koloid

Alat dan Bahan

1 gelas air susu encer

1 buah senter

Cara Kerja

- Matikan lampu ruangan/ buat ruangan menjadi gelap

- Arahkan cahaya senter ke air susu yang encer

- Perhatikan hamburan cahaya yang terjadi dalam air susu

Penjelasan :

Efek tyndall adalah salah satu sifat larutan kolois (campuran homogen). Efek tyndall adalah penghamburan cahaya oleh molekul-molekul koloid. Susu termasuk koloid, ketika seberkas cahaya jatuh ke molekul susu maka cahaya tersebut akan dihamburkan.

\section{Kesimpulan}

Guru yang inovatif adalah guru yang memiliki kreativitas dalam mengelola proses pembelajaran dengan kompetensi yang dimilikinya. Dalam menciptakan inovasi pembelajaran yang terpenting adalah kemauan dan keinginan guru untuk mengubah image belajar sebagai suatu keterpaksaan menjadi suatu kebutuhan, dengan cara membawa siswa menikmati sisi-sisi keindahan dan kemenarikan dari suatu materi pelajaran yang sedang dipelajarinya. Hal ini hanya dapat dilakukan bila guru melakukan inovasi pembelajaran menggunakan prinsip pembelajaran bermakna dan menyenangkan.

\section{Daftar Pustaka}

Amy J. Phelps \& Cherin Lee. (2003). The power of practice : what students learn from how we teach. Journal of Chemical Education, 80 (7), 829 - 832.

Carolin Rekar Munro. (2005). "Best practices" in teaching and learning : Challenging current paradigms and redefining their role in education. The College Quarterly. 8 (3), 1 - 7

Constance Blasie \& George Palladino. (2005). Implementing the professional development standards : a research department's innovative masters degree program for high school chemistry teachers. Journal of Chemical Education. 82 (4), 567 - 570.

Johnson, E. B. (2002). Contextual teaching and learning. California: A Sage Publications Company, Corwin Press, Inc

Kamisa. (1997). Kamus lengkap Bahasa Indonesia. Surabaya : Kartika.

Mel Silberman. (2002). Active learning : 101 strategi pembelajaran aktif. Yogyakarta : Yappendis.

Putra, W. S. ( 2013). Sains Seru, 99 Percobaan sains sederhana. Yogyakarta : Kata Hati 